\title{
Characterization of school-related problems and diagnoses in a Neuro-Learning Disorder Clinic
}

\section{Caracterização de queixas escolares e diagnósticos no Ambulatório de Neuro-Dificuldades \\ de Aprendizagem}

\author{
Mariana Coelho CARVALHO ${ }^{1}$ \\ Ricardo Franco de LIMA $^{2}$ \\ Gláucia Gabriela Bagattini de SOUZA² \\ Taciana Coli PIRES ${ }^{2}$ \\ Rafael PIERINI ${ }^{2}$ \\ Sonia das Dores RODRIGUES ${ }^{2}$ \\ Adriana Nobre Paula SIMÃO2 \\ Sylvia Maria CIASCA ${ }^{2}$
}

\begin{abstract}
The objective of this study was to characterize the children referred to the Neuro-Learning Disorder Clinic at the Public Hospital of the Universidade Estadual de Campinas (State University of Campinas) in 2010 focusing on the demographics, parents' concerns, and the diagnoses given by the health care professionals. A total of 203 male and female children and young people, aged 4-17 years old, attending kindergarten to high school were analyzed. The children that were referred due to school-related problems underwent interdisciplinary evaluations aiming to establish a diagnosis. After thorough evaluation, the children were treated according to their specific needs. The study sample was predominately comprised of males (67.0\%), fifth graders with average age of 10 years and 11 months. The main problems identified were global learning difficulties and inattention. The evaluation results indicated $43.8 \%$ of pedagogy-related learning difficulties and $32.2 \%$ of intellectual disability issues. The findings corroborate those of other studies on the characterization of behavior and school-related problems of children and adolescents in specialized centers. The results obtained emphasize the importance of an interdisciplinary team work to evaluate school-related problems.
\end{abstract}

Keywords: Students; Diagnosis; Learning disorders.

"V

1 Universidade Estadual de Campinas, Faculdade de Ciências Médicas, Programa de Pós-Graduação em Ciências Médicas. R. Tessália Vieira de Camargo, 126, Cidade Universitária Zeferino Vaz, 13083-887, Campinas, SP, Brasil. Correspondência para/Correspondence to: M.C. CARVALHO. E-mail: <coelho.mariana@hotmail.com>.

2 Universidade Estadual de Campinas, Faculdade de Ciências Médicas, Departamento de Neurologia. Campinas, SP, Brasil. Support: Work done by Professional Enhancement Programs - Clinical Psychology in Child Neurology and Psyco-pedagogy Applied to Child Neurology, held in partnership with the Fundação de Desenvolvimento Administrativo. 


\section{Resumo}

O objetivo do trabalho foi caracterizar as crianças encaminhadas ao Ambulatório de Neuro-Dificuldades de Aprendizagem da Universidade Estadual de Campinas em 2010. Foram analisados dados de 203 crianças e jovens, de ambos os gêneros, com faixa etária entre 4 e 17 anos de idade, cursando do ensino infantil ao médio. As crianças encaminhadas com queixas escolares passaram por avaliações interdisciplinares com objetivo diagnóstico e após o processo avaliativo foram devidamente encaminhadas para intervenções específicas conforme o caso. Na amostra de crianças atendidas houve maior frequência do gênero masculino (67,0\%), uma idade média de 10 anos e 11 meses, com maior número de pessoas cursando o $5^{a}$ ano. As principais queixas foram dificuldades globais de aprendizagem e desatenção. Dos resultados das avaliações, 43,8\% foram de dificuldades escolares de ordem pedagógica e 32,2\% de deficiência intelectual. Os achados obtidos corroboram outros estudos de caracterização de queixas escolares e comportamentais de crianças e adolescentes em centros especializados. Os dados também reforçam a importância da avaliação de equipe interdisciplinar em um processo de investigação das queixas escolares.

Palavras-chave: Estudantes; Diagnóstico; Transtornos de aprendizagem.

Learning occurs as a result of practice or experience leading to systematic changes in behavior. It is an ongoing process, that is, it begins at birth and continues throughout life. During childhood, children develop different basic skills necessary for the acquisition of reading, writing, and mathematics (Millá, 2006; Rego, 2002).

The development of scholastic skills depends on the interaction between internal factors, related to the individual, and external factors, related to learning conditions (Fonseca, 2007; Rotta, 2006).

During the process of acquisition of such skills, it is expected that children have some difficulties that reflect the natural maturational process. On the other hand, persistent difficulties should be investigated as they may be due to some kind of disorder, i.e., factors inherent to the individual (Lagae, 2008).

In general, according to the literature, learning difficulties are divided into two different groups: difficulty with school work and learning disorders. Learning difficulties have different causes: inadequate literacy instruction, teaching methods inadequate to students' learning styles and characteristics, numerous school problems. They can also be the result of neurological and genetic disorders (epilepsy and non-progressive encephalopathy during childhood, among others), psychiatric disorders and psychosocial factors (problems in the family dynamics, inadequate stimulation, and other social problems) (Ciasca, 2003; Lima, Mello, Massoni, \& Ciasca, 2006a).
On the other hand, learning disabilities are characterized by central nervous system dysfunction, and consequently, failure to process information. Thus, the child adequately receives information from the external environment (sensory input), but there is failure to integrate, process, and store this information, resulting in problems in the information output demonstrated in writing, reading, or calculation (Ciasca, 2003; Lima, Mello, Massoni, \& Ciasca, 2006b).

According to the diagnostic manual, the International Classification of Diseases (ICD-10), maintained by the World Health Organization, learning disorders are listed in the F81 category "Specific developmental disorders of scholastic skills" - classified under "Psychological Developmental Disorders" (World Health Organization, 2008). There are three types of specific learning disorders: reading (dyslexia), writing (dysorthographia), and mathematics (dyscalculia) (American Psychiatric Association, 2002; World Health Organization, 2008).

In addition, learning difficulties are common in the early years of school and are the reason of great part of referrals to education or health services. There are several national studies addressing the profile of children and youth referred for evaluation and treatment due to learning difficulties and related diagnoses (Bernardes-da-Rosa, Garcia, Domingos, \& Silvares, 2000; Ciasca \& Rossini, 2000; Cunha \& Benetti, 2009; Lima et al. 2006a; Linhares, Parreira, Maturano, \& Santa'Anna, 1993; Rodrigues, Campos, \& Fernandes, 2012; 
Romaro \& Capitão, 2003; Schoen-Ferreira, Silva, Farias, \& Silvares, 2002).

The reasons why parents sought professional child health care investigated in the Educational Psychology Screening Service of the Ribeirão Preto University Hospital. The results showed that the most frequently mentioned learning difficulties were related to school performance in general, for example: slow learning and reading problems. There were also difficulties related to changes in cognitive processes and social-emotional and functional problems (Linhares et al., 1993).

Bernardes-da-Rosa et al. (2000) conducted a study on the characterization of the psychological care provided to children with learning difficulties referred to the Psychology Department of a teaching hospital in the city of São Paulo. Data were collected from the medical records of children treated in that hospital from 1996 to 1997. The results showed that the majority of the sample was referred by health professionals, and the most frequent reason was related to specific developmental disorders and scholastic skills, followed by explicit behavioral disorders. The most frequent diagnosis was intellectual disability, followed by learning disorders. The most common recommended treatment was parental guidance, and a correlation between the reason for referrals (difficulties presented) and treatment recommendation was also found.

Schoen-Ferreira et al. (2002) characterized the socio-demographic profile of 61 adolescents aged between 10 and 19 years referred to the Psychology Department of the Centro de Atendimento e Apoio ao Adolescente (CAAA, Adolescent Medical and Support Services Center) Department of Pediatrics of the Universidade Federal de São Paulo/Escola Paulista de Medicina (Federal University of São Paulo) from 1997 to 2000. Like in a previous study, in the present study, the data was obtained from patient medical records following a protocol divided into 2 parts: one concerning the socio-demographic data and the other concerning the learning difficulties mentioned in the first psychological interview. The results showed that 27 adolescents between 13 and 15 years old, most males (54.0\%), attending elementary school (students were held back), and the most common school problems mentioned were related to learning difficulties.

Similarly, Romaro and Capitão (2003) characterized the patients who received psychological care in the clinic of the Universidade São Francisco (São Francisco University), São Paulo, between 1995 and 2000; 248 out of the 1,229 people who received psychological treatment were children, and $65.3 \%$ were male. School difficulties were the most frequent issue mentioned (19.0\%), followed by difficulties in interpersonal relationships $(12.4 \%)$, aggressive behavior (10.6\%), difficulties in family relationships (10.3\%), and eating disorders, sleep disorders, or problems with bladder control (enuresis) (9.5\%). In the present study, there are no data of the diagnoses reported.

Cunha and Benetti (2009) also evaluated the psychological care given to 499 patients in an academic clinic in the metropolitan area of Porto Alegre, Brazil, from 1999 to 2006. The authors found that children represented $51.8 \%$ of the total population who sought care; the majority were between 6 and 9 years old (56.4\%) and $67.3 \%$ were males. The most frequent referrals for care came from schools (63.5\%) and were due to learning difficulties and emotional, behavioral, and somatic problems.

In a more recent study, Rodrigues et al. (2012) investigated the issues dealt with at the Psychological Service Center of the Universidade Federal de Juiz de Fora, Minas Gerais (Federal University of Juiz de Fora). Their study showed that the most frequent referrals were related to behavioral and learning problems. Among the 1,590 children with learning difficulties that comprised their study sample, $66.0 \%$ were male. In addition, the results showed strong presence of boys aged between 7 and 13 years (45.7\%), and the predominance of referrals came from schools located on the outskirts of the city.

As for the context of the present research, two related studies were found in the literature. One study investigated school attendance problems, and it was possible to identify the profile of children treated at the Neuro-Learning Disorder Clinic at the 
Public Hospital of the Universidade Estadual de Campinas (Unicamp, State University of Campinas) in 1995 . The data showed that $48.9 \%$ of the referrals came from this same hospital (the university hospital), i.e., they were interprofessional interconsultations requested by health care professionals from different clinics of the hospital. With regard to the reasons for the referrals, 32.5\% were school problems, $44.5 \%$ were behavioral and school problems, and $23.0 \%$ did not have the basic signs of learning difficulties most of the children treated were male (71.9\%) aged $4-15$ years (average of 9 years) and attended public schools $(76.0 \%)$; the others attended private schools (8.0\%), special needs schools $(6.0 \%)$, or were not enrolled in school (10.0\%). As for the diagnoses, it was found that $44.0 \%$ of children had school difficulties indicative of pedagogical problems (Ciasca \& Rossini, 2000; Rossini \& Santos, 2001).

The other study was carried out in the same service center evaluating the patients treated in 2006. It was shown that $46.0 \%$ of the referrals were due to learning difficulties (reading, writing, calculation, literacy problems, and problems with keeping up with school work), $19.0 \%$ were due to attention and memory problems, $15.0 \%$ to behavioral problems (hyperactive or aggressive behavior), 9.0\% to oral language problems (exchanges and/or omissions), $5.0 \%$ to problems with social and interpersonal skills, $4.0 \%$ to psychological issues (irritability, sadness, fear, anxiety), and $2.0 \%$ to motor skill problems (coordination). Thirty nine percent of the diagnoses made were related to learning difficulties (neurological, psychological, and pedagogical problems), $21.0 \%$ were learning disorder and $9.0 \%$ were Attention Deficit Hyperactivity Disorder (ADHD) (Lima et al., 2006a).

As mentioned earlier, previous studies addressed different aspects of children with learning difficulties at different times in different grades. Although those studies were conducted in different places, used different sample sizes, and reported different diagnoses, important data were obtained from scientific studies that characterize this specific population. Furthermore, since the knowledge about this issue has been increasing in the last few years, further studies should be carried out on the profile of children with different types of disorders (mental and/or learning disorders), and thus new approaches to evaluation and treatment can be adopted.

Therefore, the objective of this study was to characterize the children referred to the NeuroLearning Disorder Clinic at the Public Hospital of the Clinical Hospital/Unicamp in 2010, focusing on the demographics, parents' concerns, and the diagnoses given by the health care professionals.

\section{Method}

The Neuro-Learning Disorder Clinic, located at the at the Neurology department of the Public University Hospital (Unicamp), provides interdisciplinary assessment and diagnosis of children and young people with school problems.

In general, the referrals are made by other clinics of the university hospital, public and private schools (state or municipal), or public and private health services of the metropolitan region of Campinas, São Paulo or other cities in the state of São Paulo or even other states.

As shown in Figure 1, the children were initially evaluated (under supervision) by psychologists, members of the professional enhancement program. The evaluation started with a triage of the parents or guardians, in which is using anamnesis (case history) to obtain general information about school problems and child development. Subsequently, psychological evaluation sessions were held with the child, and additional information about the child's school performance and behavior pattern was obtained from the child's teachers. At the end of this first step, the case was discussed in supervision sessions to determine the child's clinical status, and a feedback session was then held with the parents or guardians to provide them with a psychological evaluation report, instructions, and other necessary care. The most common diagnoses made during these first steps of evaluation were related to intellectual and/or sensory disability. 


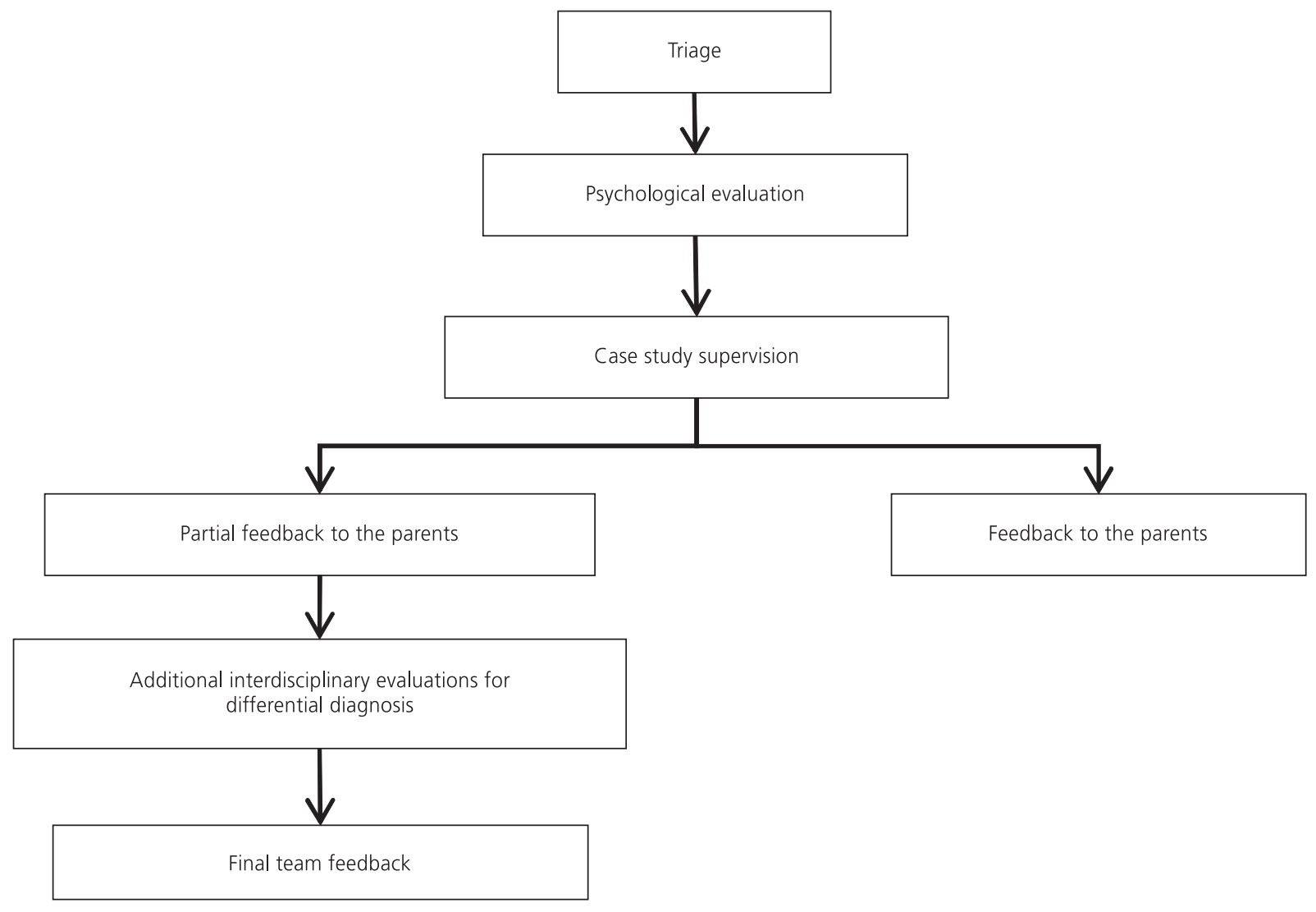

Figure 1. Steps of the evaluation process.

If learning disorders, ADHD, or other conditions were suspected, further diagnostic investigations were necessary, and additional assessment procedures were performed (neuropsychological, speech therapy, pedagogical, neurological, psychiatric, physical therapy, psychomotor). Once completed, the evaluation results were discussed among the health care team for a conclusive diagnosis, and thereafter a final feedback is provided to the parents/guardians by the team members responsible for those evaluations. Guidance on monitoring was provided to the school and treatment for specific disorders such as ADHD and Dyslexia was recommended.

\section{Instruments and Procedures}

This research was approved by the Research Ethics Committee of Faculdade de Ciências Médicas/ Unicamp (College of Medical Sciences/Unicamp), (Process $n^{\circ}$ 539/2010). A documentary research method was chosen because the data analyzed were obtained from the care services provided at the Neuro-Learning Disorder Clinic (from March/ 2010 to March/2011) by psychologists members of the Professional Enhancement Programs (Clinical Psychology in Child Neurology and Psychopedagogy applied in Child Neurology).

A protocol for data collection and tabulation was established regarding: (a) demographic profile - gender, age, and school level; (b) data related to the school problems reported and; (c) diagnostic conclusion.

The initial interview with the parents/guardians to obtain information about the school problems faced by the child and the teachers was conducted following the protocol proposed by Lima et al. (2006b). The school problems reported were divided into two general categories: (i) Dimensions: more comprehensive and referring to psychological dimensions (irritability, anxiety, fears, depressive 
symptoms, among others), behavioral dimensions (hyperactive and aggressive behavior, among others) and social dimensions (difficulty in interpersonal relationships, social isolation, etc.); (ii) Neuropsychological functions: related to learning difficulties (writing, reading, calculation, literacy problems, and poor school performance), attention/ memory (inattention, difficulty concentrating on activities at home and at school, contents learned in the classroom are easily and quickly forgotten), speech/language (exchanges and/or omission of letters and syllables during speech, difficulty understanding what is spoken, abstraction, reasoning, use of orality) and motor problems (fine and/or global motor difficulties in school and daily activities). The school problems reported involved more than one category; therefore, the analysis considered the frequency of problems reported.

A statistical analysis was conducted using the software IBM Statistical Package for Social Sciences (SPSS, version 20.0 for Windows).

\section{Results}

As shown in Table 1, the study sample was comprised of 203 children and adolescents (135 males [66.5\%] and 68 females [33.5\%]; ratio of $4: 1)$ referred for evaluation. The ages ranged between 4 and 17 years old, with an average of 10 years and 11 months (Standard Deviation - SD = 2.47), and the majority of children were was nine years old (19.7). When the sample is distributed into age groups, it can be noticed that there was a higher frequency of referrals between 7 and 10 years old (53.7\%), followed by 11 and 12 years old (23.6\%). However, there were no significant differences in the distribution ( $p=0.10$; Fisher's exact test). The age of the males ranged from 4 to 17 years old (Mean $-M=10.24, S D=2.63$ ), and the females ranged from 5 to 16 years old $(M=9.85, S D=2.13)$. There was no significant difference between the average ages between the genders $(t(203)=1.06$; $p=0.289$ ).

The school levels evaluated ranged from kindergarten to senior year of high school. There was also a child who attended a Special Education Institution (Associação de Pais e Amigos dos Excepcionais, [APAE, Parents and Friends Association of Children and Adults with Special Needs]) (0.5\%) and one child who was not enrolled in school $(0.5 \%)$. There was a higher frequency of children in the $5^{\text {th }}$ grade of middle school $(21.7 \%)$. There were no significant differences in the distribution between the school levels ( $p=0.92$; Fisher's exact test), but there was higher frequency of children who attended elementary school $\left(1^{\text {st }}-4^{\text {th }}\right.$ grades $(49.2 \%)$, followed by those between $5^{\text {th }}$ and $9^{\text {th }}$ grades $(45.8 \%)$ (Table 1$)$.

Table 1

Entire sample frequency distribution of demographic variables $(n=203)$. Campinas (SP), Brazil

\begin{tabular}{|c|c|c|c|c|c|c|}
\hline \multirow{2}{*}{ Variables } & \multicolumn{2}{|c|}{ Male } & \multicolumn{2}{|c|}{ Female } & \multicolumn{2}{|c|}{ Total } \\
\hline & $f$ & $\%$ & $f$ & $\%$ & $f$ & $\%$ \\
\hline Gender & 135 & 66.5 & 68 & 33.5 & 203 & 100.0 \\
\hline \multicolumn{7}{|l|}{ Age Group } \\
\hline 04-06 years old & 8 & 3.9 & 4 & 2.0 & 12 & 5.9 \\
\hline 07-10 years old & 72 & 35.5 & 37 & 18.2 & 109 & 53.7 \\
\hline $11-12$ years old & 27 & 13.3 & 21 & 10.3 & 48 & 23.6 \\
\hline $13-17$ years old & 28 & 13.8 & 6 & 3.0 & 34 & 16.8 \\
\hline \multicolumn{7}{|l|}{ School level } \\
\hline Kindergarten & 4 & 2.0 & 1 & 0.5 & 5 & 2.5 \\
\hline $1^{\text {st }}-4^{\text {th }}$ grade & 63 & 31.0 & 37 & 18.2 & 100 & 49.2 \\
\hline $5^{\text {th }}-8^{\text {th }}$ grade & 64 & 31.5 & 29 & 14.3 & 93 & 45.8 \\
\hline $9^{\text {th }}-12^{\text {th }}$ grade & 2 & 1.0 & 1 & 0.5 & 3 & 1.5 \\
\hline APAE & 1 & 0.5 & 0 & 0.0 & 1 & 0.5 \\
\hline Not enrolled in school & 1 & 0.5 & 0 & 0.0 & 1 & 0.5 \\
\hline
\end{tabular}


Table 2 shows the frequency of the school problems detected and reported by the parents during the initial interview or the reasons for referrals (suspected diagnosis). It can be observed in the entire sample that the most frequent school problems reported were related to global learning difficulties (reading, writing, and mathematics) (33.9\%), attention problems (24.4\%), emotional/ behavioral problems (9.7\%), and motor skill problems (9.4\%). With regard to the types of the school problems detected, $44.4 \%$ were related to global learning difficulties (reading, writing, reading comprehension, and mathematics), 33.8\% to inattention and restlessness, $6.2 \%$ to memory, motor, and oral language function, $9.7 \%$ to emotional or behavioral problems, and $5.8 \%$ to a suspected diagnosis made by other professionals (dyslexia, ADHD, or a non-specific learning disorder).

Table 2

Entire sample frequency distribution of school problems and referrals reasons. Campinas (SP), Brazil

\begin{tabular}{|c|c|c|}
\hline School problems detected and referral reasons & $f$ & $\%$ \\
\hline Global learning difficulty & 129 & 33.9 \\
\hline Reading and writing difficulty & 29 & 7.6 \\
\hline Reading comprehension difficulty & 8 & 2.1 \\
\hline Mathematics difficulty & 3 & 0.8 \\
\hline Inattention & 93 & 24.4 \\
\hline Motor restlessness & 36 & 9.5 \\
\hline Memory difficulty & 4 & 1.0 \\
\hline Motor skill problems & 5 & 1.3 \\
\hline Oral language problems & 15 & 3.9 \\
\hline Emotional/behavioral problems & 37 & 9.7 \\
\hline Hypothesis of dyslexia & 12 & 3.1 \\
\hline ADHD suspected diagnosis & 9 & 2.4 \\
\hline Non-specific learning disability suspected diagnosis & 1 & 0.3 \\
\hline Total & 381 & 100.0 \\
\hline
\end{tabular}

Note: f: Absolute frequency; ADHD: Attention Deficit Hyperactivity Disorder.

Table 3

Entire sample frequency distribution of diagnosis according to ICD-10. Campinas (SP), Brazil

\begin{tabular}{lcc}
\hline General aspects, diagnosis, and suspected diagnosis & $f$ & $\%$ \\
\hline Overview & 8 & 3.9 \\
Team evaluation & 5 & 2.5 \\
Did not continue & 1 & 0.5 \\
Revaluation requested & 11 & 5.4 \\
Emotional issues (to be confirmed) & 1 & 0.5 \\
Psychiatric issues (to be confirmed) & 12 & 5.9 \\
Under Evaluation - Suggested Diagnosis & 10 & 4.9 \\
Diagnosis of ADHD & 4 & 2.0 \\
Non-specific learning disability hypothesis/SD & 3 & 1.5 \\
School difficulty hypothesis/Dyslexia & 2 & 1.0 \\
language disorder hypothesis & 57 & 28.0 \\
Learning disorder hypothesis/ADHD & 146 & 72.0 \\
Sub-Total & 203 & 100.0 \\
Final Diagnosis & 57 & \\
\hline Total & & \\
\hline
\end{tabular}

Note: f: Absolute frequency; ADHD: Attention Deficit Hyperactivity Disorder; SD: School Difficulty; ICD-10: International Classification of Diseases-10. 
As for the diagnoses made after the evaluations, Table 3 shows that $3.9 \%$ of children were still under the care of the professional team, $2.5 \%$ interrupted the treatment recommendations, $0.5 \%$ needed reevaluation after specific intervals over the course of treatment, and $15.3 \%(n=31)$ were reexamined by the health care team for confirmation of diagnosis and/or to get a different diagnosis. The main diagnosis made was ADHD (5.9\%), followed by a non-specific learning disorder or school difficulty (4.9\%).

The remaining children $(n=146)$ completed the evaluation and according to the ICD-10 (World Health Organization, 2008), Table 4 shows that the most common diagnoses made were pedagogyrelated learning difficulties (43.8\%) and intellectual disability $(32.2 \%)$. With regard to the psychiatric diagnosis, it is observed that $6.2 \%(n=9)$ of the children evaluated had ADHD, 0.7\% $(n=1)$ had bipolar affective disorder, $0.7 \%(n=1)$ had Asperger's syndrome, and $0.7 \%(n=1)$ had Gilles de la Tourette syndrome. As for the learning disorders, $2.7 \%(n=4)$ were diagnosed with specific reading disorder (developmental dyslexia), $2.1 \%(n=3)$ with Mixed disorder of scholastic skills, and $0.7 \%(n=1)$ with other developmental disorders of scholastic skills (written expression). It was also observed that $2.1 \%(n=3)$ did not show any sign of learning difficulties.

\section{Discussion}

The aim of this research was to characterize children and adolescents with learning difficulties referred to the Neuro-Learning Disorder Clinic (Public Hospital/Unicamp) for diagnostic evaluation.

With regard to the demographic characteristics, it was observed that the majority of children were male $(66.5 \%)$, which is consistent with the findings previously reported in different studies (Cunha \& Benetti, 2009; Rodrigues et al., 2012; Romaro \& Capitão, 2003; Schoen-Ferreira et al., 2002) and

Table 4

Selected sample frequency distribution of diagnosis according to ICD-10. Campinas (SP), Brazil

\begin{tabular}{|c|c|c|}
\hline Diagnostics & $f$ & $\%$ \\
\hline \multicolumn{3}{|l|}{ Mood disorders (affective disorder) } \\
\hline F31 Bipolar affective disorder & 1 & 0.7 \\
\hline \multicolumn{3}{|l|}{ Intellectual Disability } \\
\hline F70 Intellectual Disability & 47 & 32.2 \\
\hline Borderline level of intelligence & 9 & 6.2 \\
\hline \multicolumn{3}{|l|}{ Disorders of Psychological Development } \\
\hline F81.0 Specific developmental disorders of scholastic skills & 4 & 2.7 \\
\hline F81.9 Developmental disorder of scholastic skills, unspecified & 3 & 2.0 \\
\hline F81.8 Other developmental disorder of scholastic skills & 1 & 0.7 \\
\hline Delayed development & 2 & 1.4 \\
\hline F84.5 Asperger's Syndrome & 1 & 0.7 \\
\hline \multicolumn{3}{|l|}{ School Difficulty } \\
\hline Pedagogic-related learning difficulties (SD) & 64 & 43.8 \\
\hline No sign of learning difficulties & 3 & 2.0 \\
\hline \multicolumn{3}{|l|}{ Hyperkinetic disorders } \\
\hline F90.0 Attention-Deficit Hyperactivity Disorder (ADHD) & 9 & 6.2 \\
\hline \multicolumn{3}{|l|}{ Tic disorders } \\
\hline F95.2 Tourette's disorder (Gilles de la Tourette) & 1 & 0.7 \\
\hline \multicolumn{3}{|l|}{ Hearing loss } \\
\hline H90 Conductive and sensorineural hearing loss & 1 & 0.7 \\
\hline Total & 146 & 100.0 \\
\hline
\end{tabular}


other findings of different clinics (Ciasca \& Rossini, 2000; Rossini \& Santos, 2001; Lima et al., 2006a). Lima et al (2006a) reported the ratio of number of boys to the number of girls of 2.3:1, and in this study it was found a ratio of was 4:1.

These data suggest that boys may have more learning problems than girls (Berninger, Nielsen, Abbott, Wijsmsan, \& Raskind, 2008; Liederman, Kantrowitz, \& Flannery, 2005).

As for the age of the children referred, although there were no significant differences in the distribution, the most frequent age was 9 years old (19.7\%), and when distributed into school levels, the most frequent grades were $2^{\text {nd }}$ and $5^{\text {th }}$ grades, 7-10 years old (53.7\%).

These results are similar to those of other studies, in which it was found that the highest frequency of children aged 9 years old (Ciasca \& Rossini, 2000) and 8 years and 8 months (Lima et al., 2006a). These results are understandable when considering that it is at this age that learning difficulties and differences between a child's achievement in some areas and what is expected at his or her age start to become evident.

With regard to the school level, there was a higher frequency of children in the $5^{\text {th }}$ grade in middle school (21.7\%). This result differs from that of other studies (Ciasca \& Rossini, 2000; Lima et al., 2006a; Rossini \& Santos, 2001), in which it was found that most of the children referred were enrolled in the first two-years of Elementary School.

There are a few possible reasons for the "late" referral for children with learning difficulties. The first reason is that results from the continued progression process in the school program (which establishes that the child should not be held before finishing a specific cycle of grades, for example before finishing elementary school); therefore, only in the last year of elementary school, when the school usually decides in favor of the retention, is the child referred for evaluation.

A second possible reason is that in the early school years, at first, the schools use different strategies to deal and help students with learning difficulties. If there are no improvements, the schools then refer those students to a specialized service for further evaluation.

The Ministry of Education launched the Pacto Nacional pela Alfabetização na Idade Certa (PNAIC, National Pact for Literacy at the Right Age) in 2013, which should ensure that all children are literate up to the age of 8 years old. This program provides, among other things, investment in teacher training (Brazil, 2012). Considering that a group of children who are referred for evaluation have learning disorders or other difficulties that are not pedagogy- related problems, the profile of referred children may change and can be made at a younger age again because of this government initiative.

However, it should be noted that regardless of the cause of the learning difficulty, early diagnosis is extremely important to overcome and/or minimize the issue.

It was observed that most of the school problems reported that motivated the referrals were related to learning difficulties (44.4\%) and attention problems (33.8\%). These results also corroborate those of previous studies (Lima et al., 2006a, 2006b).

Learning difficulties have also been reported in studies conducted in other services offered by clinics of psychology schools (Bernardes-da-Rosa et al., 2000; Cunha \& Beneti, 2009; Rodrigues et al., 2012; Romaro \& Capitão, 2003) or in psychology services (Schoen-Ferreira et al., 2002) and Psycopedagogy studies conducted in medical service contexts (Linhares et al., 1993).

One difference is that the present study was conducted in a diagnostic center specialized in learning and attention disorders. Thus, it is expected that the most frequent referrals are due to learning difficulties. Although the reasons for the referrals may vary greatly in psychology academic clinics, there is a prevalence of learning difficulties.

Data obtained suggest that these are common problems in childhood and adolescence and show a high demand for psychology professionals and related fields.

It was also found that school problems can be considered an "umbrella" term, i.e., learning 
difficulties may be associated with issues related to other dimensions of cognitive, behavioral, affective, and emotional development. Therefore, children with learning difficulties and with attention or oral language problems are frequently referred for evaluation.

The results of this research also demonstrate that some of the children are referred to care services with a suspected diagnosis. The majority of these diagnoses are of developmental dyslexia (F81.0 - Specific Reading Disorder) and ADHD (F90.0 - Attention Deficit Hyperactivity Disorder). However, these assumptions do not always correspond to the final diagnosis made after thorough interdisciplinary evaluation.

Of the 146 children who completed the interdisciplinary evaluation, $43.8 \%$ were diagnosed with pedagogy-related learning difficulties and $32.2 \%$ with intellectual disabilities; the two main learning difficulties detected and the main reasons for the referral of these children to the clinic.

As described in the literature, learning difficulties can occur because of a learning disorder, neurobiological dysfunction, or different types of school-related problems such as pedagogical or psychosocial issues and others (Ciasca, 2003; Lima et al., 2006b). These causes can be identified through individualized and interdisciplinary assessments or due to persistent learning difficulties throughout schooling and poor or no response to interventional procedures (school or clinical).

Although the clinic studied is specialized in the diagnosis of learning disorders, only eight children were given such diagnosis; four were diagnosed with dyslexia, three with Mixed disorder of scholastic skills (reading, writing, and calculation), and one with writing disorder. A comparison between the number of children referred to the clinic with specific learning difficulties and the suspected and final diagnoses, it can be said that they are quite different.

Similar results were found for ADHD, considering the number of children with problems related to attention and restlessness or the actually diagnosed with ADHD. Therefore, it is important to mention that the attention problems in the school context are not always primarily related to physical or neurological factors; they may be due to strict environmental factors (motivation and content understanding among others). In addition, attention may be influenced by different factors (Lima, 2005), and attention difficulties may also be symptoms of cognitive disorders in individuals with learning difficulties (Lima, Azoni, \& Ciasca, 2012).

Moreover, there are other psychological disorders that can influence school performance and be the reason for referrals requesting evaluation, for example, pervasive developmental disorders (Asperger's Syndrome), tic and mood disorders (affective disorders). However, in this study, the frequency of these diagnoses was low $(n=3)$.

It is evident that making a diagnosis is not a simple process and involves the analysis of a multitude of factors related with learning and child development. Therefore, there is not always a direct correlation between reading and writing difficulties and the diagnosis of a specific reading disorder or between attention and restlessness problems and the diagnosis of ADHD.

Based on the discussion above, it appears that the assessment made by an interdisciplinary team is very important and a more accurate diagnosis can be made with joint efforts by health care professionals. The importance of this approach lies in the fact that it determines the appropriate intervention to be used, it solves and/or minimizes learning problems, and enables to avoid the tendency to blame the child for having learning difficulties.

\section{Contributors}

M.C. CARVALHO, R.F. Lima, G.G.B. SOUZA, T.C. PIRES and R. PIERINI collaborated in the design, participated in collecting and analyzing data and writing the article. M.C.CARVALHO and R.F. LIMA collaborated in the analysis of the data, drafting and revising it. S.D. RODRIGUES, A.N.P. SIMÃO and S.M. CIASCA collaborated in drafting and revising of the article. 


\section{References}

American Psychiatric Association. (2002). DSM-IV-TR: Manual diagnóstico e estatístico de transtornos mentais ( $4^{\mathrm{a}} \mathrm{ed}$.). Porto Alegre: Artes Médicas.

Bernardes-da-Rosa, L. T., Garcia, R. M., Domingos, N. A. M., \& Silvares, E. F. M. (2000). Caracterização do atendimento psicológico prestado por um serviço de psicologia a crianças com dificuldades escolares. Estudos de Psicologia (Campinas), 17(3), 5-14. http://dx. doi.org/10.1590/s0103-166X2000000300001

Berninger, V. W., Nielsen, K. H., Abbott, R. D., Wijsman, E., \& Raskind, W. J. (2008). Gender differences in severity of writing and reading disabilities. Journal of School Psychology, 46(2), 151-172.

Brasil. Ministério da Educação. (2012). Portaria n 867, de 4 de julho de 2012. Institui o Pacto Nacional pela Alfabetização na Idade Certa e as ações do Pacto e define suas diretrizes gerais. Diário Oficial da União, Seção 1.

Ciasca, S. M. (Org.) (2003). Distúrbios de aprendizagem: proposta de avaliação multidisciplinar. São Paulo: Casa do Psicólogo.

Ciasca, S. M., \& Rossini, S. D. R. (2000). Distúrbio de aprendizagem: mudanças ou não? Correlação de dados de uma década de atendimento. Temas sobre Desenvolvimento, 8(48), 11-16.

Cunha, T. R. S., \& Benetti, S. P. C. (2009). Caracterização da clientela infantil numa clínica-escola de Psicologia. Boletim de Psicologia, 59(130), 117-127.

Fonseca, V. (2007). Dificuldades de aprendizagem: na busca de alguns axiomas. Revista Psicopedagogia, 24(74), 135-148.

Lagae, L. (2008). Learning disabilities: Definitions, epidemiology, diagnosis, and intervention strategies. Pediatric Clinics of North America, 55(6), 1259-1268.

Liederman, J., Kantrowitz, L., \& Flannery, K. (2005). Male vulnerability to reading disability is not to be a myth: A call for new data. Journal of Learning Disabilities, 38(2), 109-129.

Lima, R. F. (2005). Compreendendo os mecanismos atencionais. Revista Ciências e Cognição, 6,113-122.

Lima, R. F., Azoni, C. A. S., \& Ciasca, S. M. (2012). Attentional performance and executive functions in children with learning difficulties. Psicologia: Reflexão e Crítica, 24(4), 685-691.

Lima, R. F., Mello, R. J. L., Massoni, I., \& Ciasca, C. M. (2006a). Dificuldades de aprendizagem: queixas e diagnósticos em um serviço de neurologia infantil. Revista Neurociências, 14(4), 185-190.

Lima, R. F., Mello, R. J. L., Massoni, I., \& Ciasca, C. M. (2006b). Frequência de antecedentes familiares e análise de queixas em crianças com dificuldades de aprendizagem. Temas sobre Desenvolvimento, 15(8586), 30-34.

Linhares, M. B. M., Parreira, V. L. C., Maturano, A. C., \& Santa'Anna, S. C. (1993). Caracterização dos motivos da procura de atendimento infantil em um serviço de psicopedagogia clínica. Medicina (Ribeirão Preto), 26(2), 148-160.

Millá, M. G. (2006). Atención temprana de las dificuldades de aprendizaje. Revista de Neurología, 42(Supl.2), S153-S156.

Rego, T. C. (2002). Vygotsky: uma perspectiva histórico-cultural da educação. Rio de Janeiro: Vozes.

Rodrigues, M. C., Campos, A. P. S., \& Fernandes, I. A. (2012). Caracterização da queixa escolar no Centro de Psicologia Aplicada da Universidade Federal de Juiz de Fora. Estudos de Psicologia (Campinas), 29(2), 241-252.

Romaro, R. A., \& Capitão, C. G. (2003). Caracterização da clientela da clínica-escola de psicologia da Universidade São Francisco. Psicologia: Teoria e Prática, 5(1), 111-121.

Rossini, S. D. R., \& Santos, A. A. A. (2001). Fracasso escolar: estudo documental de encaminhamento. In F. F. Sisto, E. Boruchovitch, L. D. T. Fini, R. P. Brenelli, \& S. C. Martinelli. Dificuldades de aprendizagem no contexto psicopedagógico (pp.214-235). Petrópolis: Vozes.

Rotta, N. T. (2006). Dificuldades para aprendizagem. In N. T. Rotta, L. Ohlweiler, \& R. S. Riesgo. Transtornos da aprendizagem: abordagem neurobiológica e multidisciplinar (pp.113-123). Porto Alegre: Artes Médicas.

Schoen-Ferreira, T. H., Silva, D. A., Farias, M. A., \& Silvares, E. F. M. (2002). Perfil e principais queixas dos clientes encaminhados ao Centro de Atendimento e Apoio Psicológico ao Adolescente (CAAA) - UNIFESP/EPM. Psicologia em Estudo (Maringá), 7(2), 73-82.

World Health Organization. (2008). CID-10: Classificação de transtornos mentais e de comportamento: descrições clínicas e diretrizes diagnósticas. Porto Alegre: Artes Médicas.

Received: February 4, 2014

Final version: November 20, 2014

Approved: April 19, 2015 
